\title{
OBITUARIES
}

\section{JAMES ALLEN LANCASTER}

\author{
$1894-1992$
}

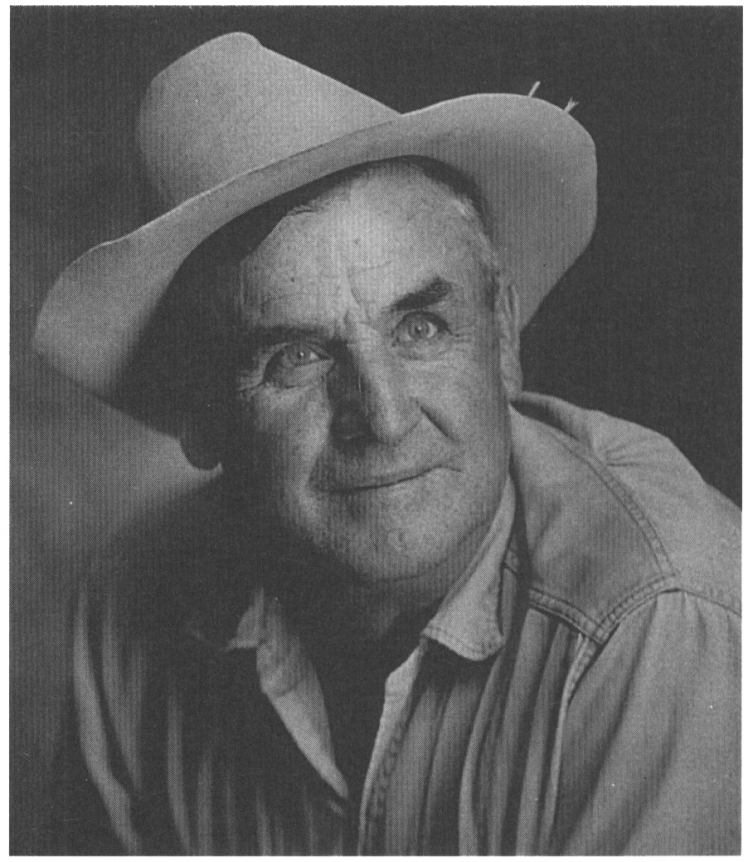

$\mathrm{J}$

ames Allen (Al) Lancaster was born in Clifton, Tennessee, on September 4, 1894. When he was seven, his family moved to the Oklahoma panhandle to homestead. Life was tough in those days, and $\mathrm{Al}$ spent more time helping with the farm than he did in school. At 21 years of age he finished the eighth grade--the last of his formal education.

He moved to Baca County, Colorado, in 1916 to file his own homestead claim, then served in the U.S. Army from 1917 to 1918. In 1922 he decided to settle in southwest Colorado to try his luck at becoming a bean farmer. He found land near the Lowry Ruin in the beautiful Montezuma Valley northwest of Cortez, not too distant from Mesa Verde. He married Alice Pigg, who would be his lifelong partner, and the two of them patented their land to begin farming and raise a family. Al earned a reputation as a hard worker, a good mule skinner, and an expert stonemason, skills sorely needed to supplement the meager living a family could gain from farming the country abandoned by the Anasazi six centuries earlier.

In 1928 a young archaeologist named Paul Martin came to southwest Colorado to undertake field- 
work under the auspices of the Denver Museum of Natural History. Martin had learned about the area at the first Pecos Conference held the year before. Relying heavily on local expertise, he offered Lancaster a job digging and locating sites. Al held out for $\$ 5.00$ a day, which Martin reluctantly agreed to pay. By 1930, when Martin (then affiliated with the Field Museum of Natural History in Chicago) began excavations at the Lowry Ruin, Al was his top hand and his salary had been increased to $\$ 6.00$ a day. He was 36 years old and had found his calling. Perhaps the experience he gained through hard work at a variety of jobs is what did it, perhaps it was more his natural ability to read the dirt and understand the past. Whatever qualities make up a good field archaeologist, Al Lancaster had an abundance of them, and archaeologists working in the area recognized it.

Al worked with Martin at Lowry (one of the northernmost Chacoan outliers) during the 1930 and 1931 field seasons, acting as field foreman on the excavation of Lowry pueblo itself and its associated great kiva. However, his work with Martin was cut short in the fall of 1931 when John Otis Brew, of the Peabody Museum at Harvard University, hired him to assist in the excavations at Alkalai Ridge in southeastern Utah. This was the start of a lasting professional relationship and personal friendship between the two men. Al worked three more field seasons for Brew at Alkalai Ridge, and was instrumental in the selection of Site 13, long considered the type site for the Pueblo-I period in the Southwest.

In 1934, at the age of $40, \mathrm{Al}$ began a 30 -year career with the National Park Service at Mesa Verde. The first few years, however, were interrupted by a stint with Brew in northeastern Arizona. From Alkalai Ridge, Brew had moved to the Peabody Museum's Awatovi project, investigating that ancestral Hopi site on Antelope Mesa. For five field seasons, Al was an integral part of this project, serving as assistant director and supervising the fieldwork of both graduate students and Hopi crew members.

In 1939, at the end of the Awatovi project, Lancaster returned to full-time duty at Mesa Verde. While working earlier with both Martin and Brew, he had been introduced to many other southwestern archaeologists who were impressed with his skills and kept his talents in mind for future excavations of their own. One of these was Earl Morris, and Al loved to recount Morris's promise when the two first met at Alkalai Ridge - that if his (Morris's) "ship ever came in," Lancaster would have a job. This happened when Morris was offered a contract to conduct stabilization of some of the cliffhouse structures in Mesa Verde. Morris took the job only under the condition that Al Lancaster would do the work; thus was launched Al's career in the country's most famous archaeological park.

His work at Mesa Verde through the years comprised both excavation and stabilization. Practical knowledge of basic construction techniques and stonemasonry served him well, making him Mesa Verde's expert in stabilization; before long his expertise was incorporated in most of the now wellknown structures in the park, including Cliff Palace, Spruce Tree House, Square Tower House, Balcony House, Sun Temple, Farview, Mug House, Step House, and Spring House.

Stabilization techniques used by the Park Service in the 1930s and 1940s would raise eyebrows today. At that time there was no policy against the use of structural steel (screw jacks, iron rails, etc.), nor was reconstruction of masonry walls seen as inappropriate if it was considered important to the long-term structural stability of the site. Regardless of modern criticism of early stabilization efforts, sites such as Cliff Palace, Balcony House, and Spruce Tree House simply would not have endured the millions of visitors that have passed through their walls over the last 60 years had they not been stabilized by Lancaster. Though perhaps not apparent to the untrained eye, the impact of the "bean farmer" on the archaeological education of the Mesa Verde visitor through the years has been extremely significant.

Lancaster's expertise put him in demand for archaeological tasks in a variety of locations and situations in the 1940s and 1950s. He worked again with Earl Morris at the Falls Creek Basketmaker II sites near Durango. He worked at Aztec, Chaco Canyon, El Morro, and Hovenweep for the Park Service, and of course at Mesa Verde. He was personally responsible for much of the excavation, stabilization, and interpretation of the sites on the popular Ruins Road loop on Chapin Mesa. He became involved with the University of Colorado's archaeological field school conducted at Mesa Verde by Robert Lister. 
There he had the opportunity to act as mentor to the students attending the field school, many of whom continued their careers in archaeology. Then in 1958, the Wetherill Mesa project was initiated at Mesa Verde, and Lancaster was instrumental in either overseeing or assisting with much of the excavation and stabilization of the eight major sites investigated by that project from 1959 through 1962.

Al formally retired from the National Park Service in 1964 at the age of 70 with 30 years of distinguished service. Yet he never really retired and, amazingly, continued practicing archaeology for many, many more years. In 1964-1965 he assisted Emil Haury with his reinvestigation of Snaketown, getting his first taste of Hohokam archaeology at the age of 70. Then, from 1965 to 1977, he was associated with the University of Colorado's Mesa Verde Archaeological Research Center, initially under the direction of Bob Lister, and later Dave Breternitz, helping students in their excavation and stabilization projects. It was with this affiliation that Al returned to Lowry Ruin in 1966-1967, and again in 1974, to assist in the stabilization of the site he helped Paul Martin excavate in the 1930s.

Lancaster's accomplishments in archaeology did not go unrecognized by others. In 1962 Secretary of the Interior Stuart Udall awarded him the Interior Department's Distinguished Service Award. In 1964 Superintendent Art Thomas of Mesa Verde National Park awarded him the park's Outstanding Performance Award. In 1977 the Regents of the University of Colorado gave him their Distinguished Service Award. And in 1989 he received the Byron S. Cummings Award in archaeology.

In 1959 a special plaque was presented to $\mathrm{Al}$ by Jo Brew at the Pecos Conference. Its message is worth repeating here:

Loyal friend and valued colleague; discoverer, excavator, preserver. Your example has inspired us. We have benefitted by your assistance and advice. Mesa Verde, Alkalai Ridge, Awatovi, Hovenweep, Tumacacori and Chaco Canyon bear witness to your skills. The archaeologists of the Southwest salute you.

The plaque was signed by some 84 archaeologists, among them Watson Smith, Alfred Kidder, Jesse Nusbaum, Erik Reed, Clyde Kluckholn, Jo Brew, Harold Colton, and other scholars of the American Southwest.

Al Lancaster died a natural death on October 28, 1992, at the age of 98 . Only four months before his death, he visited a Pueblo-III site which I was excavating with my own archaeological field school, located only a few hundred yards from the homesite where he and Alice had settled 70 years previously. He gave us good advice about our digging, and my students marveled at both his agility and his phenomenal memory. We were all pulling for him to make 100, but that was not to be. His partner Alice died nine months later at the age of 91 years.

Sometimes in archaeology we put too much emphasis on formal education, at the expense of allowing natural talent to emerge and develop. Fortunately for the profession, this was not the case with $\mathrm{Al}$ Lancaster. Martin, Brew, Morris, Haury, Lister, and others recognized his abilities and took advantage of them. Well-known professionals who became leaders in the field of southwestern archaeology were privileged to have learned from him. We are indeed fortunate he did not stick with bean farming. We miss him sorely, and we miss his humor, his talents, and his contributions to our field.

W. JAMES JUDGE

\section{Note}

The photograph of Al Lancaster was taken by Fred Mang, Jr., National Park Service photographer. The information presented here could not have been compiled without the help of Bliss Bruen, who captured reminiscences from both $\mathrm{Al}$ and Alice Lancaster on videotape, nor without help from the Lancaster children, Mary, Judy, Jimmie, William, John, and Sarah. Perhaps the most important source, however, was the tribute to Al and Alice written by Jenny Adams in Pinto Beans and Prehistoric Pots: The Legacy of Al and Alice Lancaster (1994, Archaeological Series No. 183, Arizona State Museum, Tucson).

\section{Bibliography of James Allen Lancaster}

1943 Excavation of Mesa Verde Pit Houses. American Antiquity 9:190-198.

1954 Archaeological Excavations in Mesa Verde National Park, Colorado, 1950 (with J. M. Pinkley, P. F. Van Cleave, and D. Watson). Archaeological Research Series No. 2. National Park Service, Washington, D.C.

Excavations at Site 16 (with J. M. Pinkley). In Archaeological Excavations in Mesa Verde National Park, Colorado, 1950, edited by J. A. Lancaster, P. F. Van Cleave, and D. Watson, pp. 
23-86. Archaeological Research Series No. 2. National Park Service, Washington, D.C.

Excavation of Sun Point Pueblo (with P. F. Van Cleave). In Archaeological Excavations in Mesa Verde National Park, Colorado, 1950, edited by J. A. Lancaster, P. F. Van Cleave, and D. Watson, pp. 87-111. Archaeological Research Series No. 2. National Park Service, Washington, D.C.

Excavation of Two Late Basketmaker III Pithouses (with D. Watson). In Archaeological Excavations in Mesa Verde National Park, Colorado, 1950, edited by J. A. Lancaster, P. F. Van Cleave, and D. Watson, pp. 7-22. Archaeological Research Series No. 2. National Park Service, Washington, D.C.

1968 The Salvage Excavation of Sites 353 and 354, Chapin Mesa. In Contributions to Mesa Verde Archaeology V: Emergency Archaeology in Mesa Verde National Park. Colorado, 1948-1966, edited by R. Lister, pp. 57-59. University of Colorado Press, Boulder.

An Archaeological Test at Site 80, Chapin Mesa. In Contributions to Mesa Verde Archaeology V: Emergency Archaeology in Mesa Verde National Park. Colorado, 1948-1966, edited by R. Lister, pp. 61-62. University of Colorado Press, Boulder.

Test Excavation on Site 391: A Typical "Burned
Rock Area" on Chapin Mesa (with L. J. Abel). In Contributions to Mesa Verde Archaeology V: Emergency Archaeology in Mesa Verde National Park. Colorado, 1948-1966, edited by R. Lister, pp. 63-64. University of Colorado Press, Boulder.

Site 1060: A Basketmaker III Pithouse on Chapin Mesa (with A. C. Hayes). In Contributions to Mesa Verde Archaeology V: Emergency Archaeology in Mesa Verde National Park. Colorado, 1948-1966, edited by R. Lister, pp. 65-68. University of Colorado Press, Boulder.

Archaeological Salvage at Sites 1030 and 1066, Prater Canyon (with L. J. Abel and D. Watson). In Contributions to Mesa Verde Archaeology V: Emergency Archaeology in Mesa Verde National Park. Colorado, 1948-1966, edited by R. Lister, pp. 33-36. University of Colorado Press, Boulder.

1975 Badger House Community. Mesa Verde National Park (with A. C. Hayes). Archaeological Research Series No. 7-E. National Park Service, Washington, D.C.

In addition to the published reports listed here, $\mathrm{Al}$ Lancaster is credited with a total of 48 unpublished reports on the stabilization of major ruins and other sites in Mesa Verde National Park and Hovenweep National Monument. These reports are on file at Mesa Verde National Park. 